\title{
ろう石を骨材として使用したとをの耐火れんが 素地の焼成充てん性の変化についで*
}

\section{1. 緒}

\section{言}

著者らはさきに, 配合物の一成分としてろう石を微 粉として使用した場合，粘土質耐火れんが素地は， $1000^{\circ} \mathrm{C}$ までは弛緩した充てん性を示し，高温での暁 結が困難になることを推論した.

このことは現場的な経験からも裏付けされることで, ろう石が特にパイロフィライト，石英等からなってい る場合は焼結しにくい（ただし，ろう石の構成鉱物と してかなりのセりサイトを含んでいる場合は別であ る).

しかし，ろう石を粗粒として使用した場合は低温で 焼成き裂を生じやすい欠点はあるが，他面密な充てん 性を示す傾向がある.

本報は粘土質耐火れんが素地について，パイロフィ ライト，石英を主成分としたろう石を骨材として添加 した場合，焼成後の充てえ性に現われる变化について
長 崎 勧** 渡辺明**

調べたものである.
2. 試
料

ろう石には豊栄産ろう石を使用した。使用した豊栄 産ろう石のX線回折図を第 1 図に示す。これによると パイロフィライト，石英のほかにカオリナイトが含有 されていることがわかる(セリサイトを含まない).

基礎配合は枝下水七シャモットと枝下木節より調合 し，その割合，粒度は第 1 表に示すとおりである。ま た使用した原料の化学成分を第 2 表に示す.

基礎配合に対して，ろう石を（1）5.66〜4.00 mm,

第 1 表 基礎配合割合

\begin{tabular}{|c|c|c|c|}
\hline & 粒 径 $(\mathrm{mm})$ & 割 & 合 $(\%)$ \\
\hline 枝下水ヒシャモット & $4 \cdot 00 \sim 2 \cdot 83$ & & 40 \\
\hline 枝 下 木 節 & $0.84<$ & & 60 \\
\hline
\end{tabular}

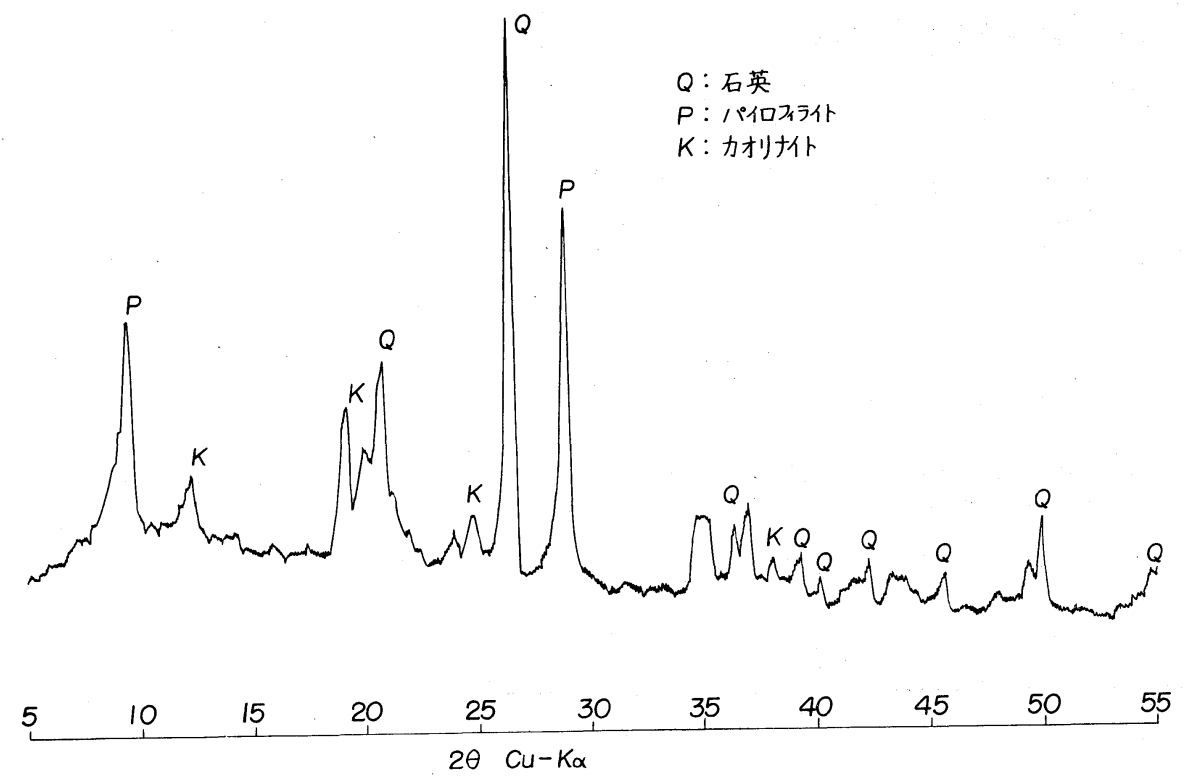

第1図豊栄弓う石の $\mathrm{X}$ 線回折図形

* 原稿受付 昭和 37 年 5 月 4 日 $* *$ 正員 九州耐火煉瓦侏式会社 
(2) $4.00 \sim 2.83 \mathrm{~mm}$, ( 3 ) $2.83 \sim 2.00 \mathrm{~mm}$, (4) 2.00 $\sim 1.00 \mathrm{~mm}$, ( 5 ) $1.00 \sim 0.84 \mathrm{~mm}$, (6 ) $0.84 \mathrm{~mm}<$ の 6 段階の粒度に調整し，それぞれ $3,5,10,15 \%$ を添 加した.

配合物はウエットパン（最大混練可能量 $2 \mathrm{~kg}$ )を用い， はじめ乾燥状態でよく混合した後，水分 $6 \%$ を添加し て混練した。この際粗粒がこれ以上に粉砕されないよ う留意した。

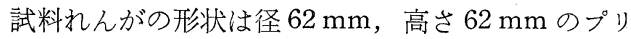
ケット状のもので，油圧 $200 \mathrm{~kg} / \mathrm{m}^{2}$ で成形した。また 必要に応じて並形れんがの形状のものも成形した。

焼成はトンネル敜で，最高温度 $1410^{\circ} \mathrm{C} ， 48$ 時間焼 成を行なった。そのときの焼成上昇温度と時間との関 係を第 2 図に示す。

\section{3. 試料れんがの物理性質とその外観}

第 3 表に試料れんがの物理性質および成形後のかさ 比重を示す。成形後のかさ比重はよく乾燥したものに ついて測定した．第3表に記された符号の項で，0 ろう石の添加されていない基礎配合を焼成したもの， その他のもので，たとえば3-(1) というのは上述した ように，5・66〜4.60 mm の粒径をしたろう石 $3 \%$ を， 基礎配合に添加外パーセントした素地を暁成したもの である。

15一（1)はかなりき裂を生じており，10-(1)，15-(2)， 10-(2)，15-(3)は微少き裂が生じていた。中でも特に 15-(1)は第 3 図に示したように，ろう石粒子が膨張し てれんが表面外に突きだしており，この突出部分は粒 子を中心としてき裂が発生している。

\section{4．充てん性の表わし方とその適用結果}

充てん性を表わす方法として，見掛気孔率，かさ比 重, 圧縮強度等が多くの報告者によって使われている。

しかし，この方法はあくまでも充てん性そのものを 表わしたものではなく，中でも見掛気孔率，圧縮強度 は間接的な目安にすぎない，また成形時の充てんによ

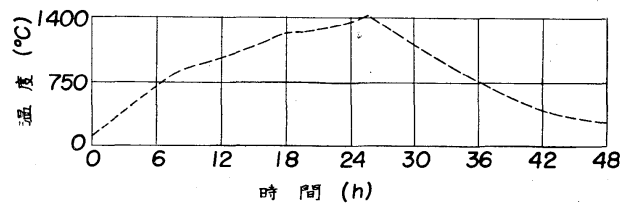

第 2 図 トンネルキルンの暁成曲線
第 3 表 試験れんがの物理性質

\begin{tabular}{|c|c|c|c|c|}
\hline 符 号 & 見掛気孔率 & かさ比重 & $\begin{array}{l}\text { 成形後の } \\
\text { かさ比重 }\end{array}$ & 真比重 \\
\hline 0 & $26 \cdot 0$ & $1 \cdot 95$ & $1 \cdot 86$ & $2 \cdot 65$ \\
\hline $3-(1)$ & $23 \cdot 0$ & $2 \cdot 05$ & $1 \cdot 90$ & $2 \cdot 65$ \\
\hline $5-(1)$ & $22 \cdot 5$ & $2 \cdot 07$ & 1.92 & $2 \cdot 64$ \\
\hline $10-(1)$ & $16 \cdot 2$ & $2 \cdot 13$ & 1.93 & $2 \cdot 64$ \\
\hline $15-(1)$ & $14 \cdot 0$ & $2 \cdot 20$ & $1 \cdot 95$ & $2 \cdot 63$ \\
\hline $3-(2)$ & $23 \cdot 8$ & $1 \cdot 97$ & 1.83 & $2 \cdot 65$ \\
\hline $5-(2)$ & $23 \cdot 0$ & $2 \cdot 00$ & $1 \cdot 91$ & $2 \cdot 65$ \\
\hline $10-(2)$ & $19 \cdot 0$ & $2 \cdot 10$ & $1 \cdot 91$ & $2 \cdot 65$ \\
\hline $15-(2)$ & $16 \cdot 3$ & $2 \cdot 13$ & $1 \cdot 93$ & $2 \cdot 63$ \\
\hline $3-(3)$ & $24 \cdot 2$ & 1.96 & 1.89 & $2 \cdot 65$ \\
\hline $5-(3)$ & $23 \cdot 3$ & $2 \cdot 00$ & $1 \cdot 89$ & $2 \cdot 63$ \\
\hline $10-(3)$ & $20 \cdot 3$ & $2 \cdot 08$ & $1 \cdot 91$ & $2 \cdot 65$ \\
\hline $15-(3)$ & $18 \cdot 8$ & $2 \cdot 10$ & $1 \cdot 92$ & $2 \cdot 64$ \\
\hline $3-(4)$ & $24 \cdot 6$ & $1 \cdot 96$ & $1 \cdot 88$ & $2 \cdot 65$ \\
\hline $5-(4)$ & $24 \cdot 0$ & $1 \cdot 96$ & $1 \cdot 89$ & $2 \cdot 65$ \\
\hline $10-(4)$ & $23 \cdot 0$ & $2 \cdot 00$ & 1.90 & $2 \cdot 64$ \\
\hline $15-(4)$ & $22 \cdot 3$ & $2 \cdot 02$ & $1 \cdot 92$ & $2 \cdot 63$ \\
\hline $3-(5)$ & $25 \cdot 5$ & $1 \cdot 95$ & $1 \cdot 88$ & $2 \cdot 64$ \\
\hline $5-(5)$ & $25 \cdot 0$ & $1 \cdot 95$ & $1 \cdot 89$ & $2 \cdot 65$ \\
\hline $10-(5)$ & $25 \cdot 0$ & $1 \cdot 95$ & $1 \cdot 89$ & $2 \cdot 63$ \\
\hline $15-(5)$ & $25 \cdot 0$ & $1 \cdot 95$ & $1 \cdot 90$ & $2 \cdot 63$ \\
\hline $3-(6)$ & $2 \cdot 61$ & $1 \cdot 94$ & $1 \cdot 88$ & $2 \cdot 65$ \\
\hline $5-(6)$ & $2 \cdot 63$ & $1 \cdot 94$ & $1 \cdot 88$ & $2 \cdot 65$ \\
\hline $10-(6)$ & $2 \cdot 68$ & $1 \cdot 94$ & $1 \cdot 89$ & $2 \cdot 64$ \\
\hline $15-(6)$ & $2 \cdot 73$ & $1 \cdot 93$ & $1 \cdot 90$ & $2 \cdot 63$ \\
\hline
\end{tabular}

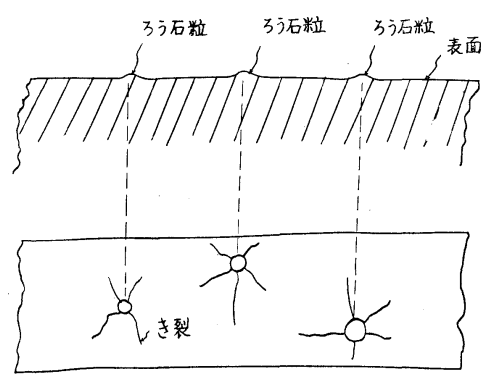

第 3 図 試料れんが 15-(3) の外観

第 2 表 原 料 の 化学成 分

\begin{tabular}{l|c|c|c|c|c|c|c}
\hline & 灼熱減 量 & $\mathrm{SiO}_{2}$ & $\mathrm{Al}_{2} \mathrm{O}_{3}$ & $\mathrm{Fe}_{2} \mathrm{O}_{3}$ & $\mathrm{CaO}$ & $\mathrm{MgO}$ & Total \\
\hline 枝下水ヒシャモット & 0.10 & 55.80 & 41.50 & 2.00 & 0.50 & 0.40 & 100.30 \\
枝下 木 節 & 15.30 & 47.00 & 35.00 & 1.90 & 0.50 & 0.30 & 100.10 \\
豊 栄万5 石 & 6.90 & 53.78 & 37.20 & 0.90 & 0.23 & 0.12 & 99.14 \\
\hline
\end{tabular}


って焼成後の物理性質が多分に左右されるこ・とが容易 に考えられるので，上記 3 因子による比較は当を得て いるものとは言えない。

著者らは G.K. Layden らが用いた密度パラメータ 一 (densification parameter) で表わしてみた。 Kを 密度パラメーターとすれば

$$
K=\left(1 / 3 \sqrt[3]{D_{p}}-1 / 3 \sqrt[3]{D_{F}}\right) /\left(1 / 3 \sqrt[3]{D_{p}}-1 / 3 \sqrt[3]{D_{T}}\right)
$$

ただし， $D_{p}$ は成形後のかさ比重， $D_{F}$ は暁成後のか さ比重, $D_{T}$ は真比重である。

第 3 表の結果よりKを算出し，それを図示化すれば 第4図のようになる、これによると，ろう石の粒径 1.00 mm 以上のものを添加すれば第 4 図で曲線 (1), (2)，(3)，(4) がこれにあたる。そ穴添加量の増加に 伴って充てんがよくなる。しかし，1.00 mm 以下（曲 線 (5)，(6) の場合)の粒径のものを添加した場合は, 添加量の増加に伴ってゆるやかなこう配を描いて充て んが悪化する傾向を示す。

\section{5. ショアー硬度の測定による検討}

ショアー型硬度計(島津製作所製)を用いて試料れん がの表面をグラインダーで平滑にして後, 硬度を測定 した，既報でも述べたようにシショア一硬度は試料れ んがのかたさのみ在測定するのではなく，小さな重錘 の反発する高さを硬度数とした反発硬度であって，か たさを含めた組織の強じんさというようなものを測定 しているものである。

試料れんがの含有する結晶相，ガラス相，空吵等の 相互の量的な割合や幾何学的な分布状態と密接な関係 があり，単にKの值のみでは充てん性を表わしえても，

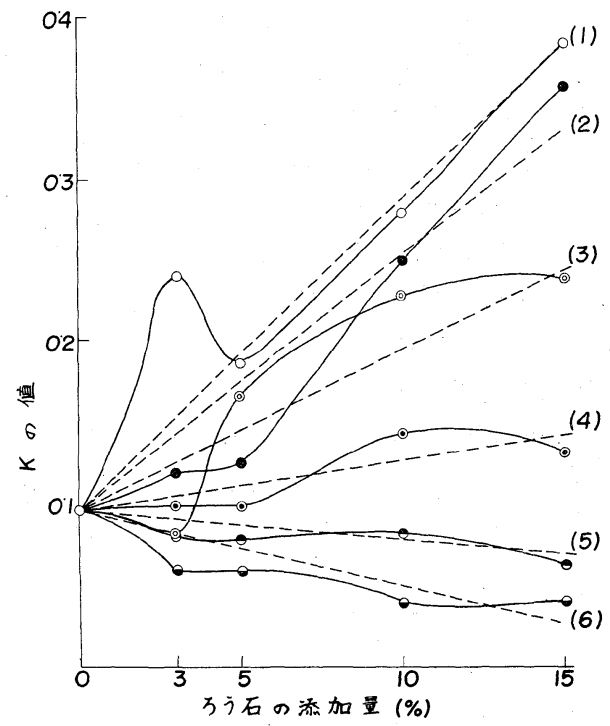

第4図 $K$ の值とろう石の添加量ならび に粒径との関連
それらの粒子間の接着度を表わすことはできない、シ ヨアー硬度はその接着度をも含めた值であると思われ るので，特に着目したわけである。ショア一硬度の測 定結果を第 5 図にまとめて示す。

第 5 図によると，Kの值と大略同じ傾向を示してお り，充てん性のよいものは粒子間の接着も良好なこと がうかがわれる。

\section{6. 考察}

第 4 図から低温での充てんの良否が，焼成後の充て んに影響を与えることがうかがわれる。すなわち，ろ う石 $1.00 \mathrm{~mm}$ 以上のもの在添加した場合は，空吵容 積の变化は極度に低下し, $1.00 \mathrm{~mm}$ 以下のものを添加 した場合は，逆にろう石粒子の表面積の増加とともに， その変化は極度に高められるものと考えられる。また 著者らは第 3 図の実験結果より次のことを推定した。 すなわち，細粒のろう石粒子を添加した場合，ての膨 張の絶対量は小さく，しかも分散しているために，ろ う石粒子を囲んでいる粒子群を押しのける力が小さい. したがってろう石粒子を中心としたわずかな範囲にし か押しのける力が影響を及ぼさない，そのために粒子 間の空吵容積の非相似的な变化でとどまる，しかしな がら粗粒のろう石粒子を添加した場合はその膨張の紨 対量は大きいので，ろう石粒子を中心とした接触粒子 間だけではなく，かなりの範囲にまで粒子群を押しの けようとする力が及ぶわけで，その力と素地を収縮さ せようとする収縮力とが反発し合って，より密な充て ん構造をとるのではないかと考えられる。

粗粒のろう石を添加すると充てんがよくなる一方， 焼結反応も促進されていることが第 5 図より推察しう る。すなわち添加ろう石の粒子を細かくすればするほ ど，その空隙容積の非相似的な変化量は大きくなるの で，それだけ粒子と粒子との接触した点の移動が激し くなり，焼結反応は進行しにくくなる，逆に粗くすれ ば，その変化量は小さくなり，粒子と粒子との接融し た点が動きにくくなり，焼結反応は容易になると考え ることができる。

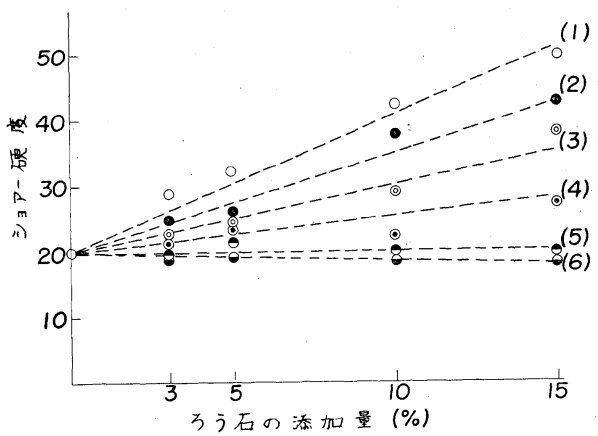

第 5 図試料れんがのショアー硬度とろう石 添加量ならびに粒径との関連 


\section{7. 総括}

著者らは素地にろう石を添加した場合に，そのろう 石の粒度によって異なる焼成後の充てん性に及ぼす影 響を調べた。

その結果，1.00 $\mathrm{mm}$ 以上のろう石粒子を添加した場 合はその添加量の増加にともなって充てんはよくなる. しかし，1.00 mm 以下のろう石の細粒を添加した場合 は逆に充てんを悪くする。

この原因は細粒の場合はそのろう石の膨張が単にろ う石粒子と接する粒子との空隙容積の非相似的な変化 のみでとどまり，いわゆる弛緩した充てん構造をとる。
しかし，粗粒の場合は単にろう石粒子と接する粒子ば かりではなく，他の粒子群にまでそのろう石の膨張が 影響し, 素地本来の収縮と反発し合い, より密な充て ん構造をとるからであろうと推定される。

\section{参 考 文 献}

1）長崎勧, 渡辺明, 吉崎一弘, 梅屋薰, 案協, 69 [10], 323 (1961)

2) 長崎勧, 渡辺明, 吉崎一弘, 梅屋薰, 材料訊験, 11, 107, 510 (1962)

3) G.K. Layden and M.C. Mcquarrie, J. Am. Ceram. Soc., 42, 2, 89 (1959)

4）長崎衔, 吉崎一弘. 渡辺明, 窯協, 69[8], 232 (1961)

5）長崎勧, 渡辺明, 吉崎一弘, 梅屋薰, 材料試験, 11, 108,568 (1962)
(6 頁より)

\section{理論的応力集中係数と Highly Stressed Volume の} 考えによる切欠係数との関係 (A Relation between Theoretical Stress Concentration Factor and Fatigue Notch Factor Deduced from the Concept of Highly Stressed Volume) R. Kugnel, Proc. ASTM, Vol. 61, pp. $732 \sim 748$ (1961)

実際の fatigue design に用いうるように, 簡単な そうして適切な関係式を求めることを目標にしている。 現在報告されている, 疲労強度に関するデータにおけ る寸法効果および形状効果は, 統計学的な考えに基づ く“Highly Stressed Volume”(たとえば, 最大応 力の $95 \%$ 以上の応力を受ける材料の体積)が増加する と, 疲労強度が減少するという実験的事実によって説 明することができる。そうして，この事実に基づいた 単純な解析によって, 形状係数と切欠係数の関係が議 論されている。

実用上は切欠係数 $K_{f}$ を知ることが最も重要である が， $K_{f}$ は,この解析に基づけば, 理論的な形状係数 $K_{t}$, 切欠材の切欠底半径 $r_{n}$, , 平滑材の底半径 $r_{s}$ (実 際上, 平滑材の場合でも切欠底半径に相当する半径 $r_{s}$ を求めることができるとしている)，および試験片の 直径 $d$ の関数として表示しうる。すなわち.

$$
K_{f} / K_{t}=\left(V_{n} / V_{s}\right)^{0.034}
$$

は平滑材, あるいは切欠材の疲労強度) の関係が, 試 験片の材料や形状や寸法に関係なく，一定なこう配を もつ直線によって近似しうるため, そのこう配を測定 した值から求めたものである。 $V_{n}$ と $V_{s}$, それぞれ 切欠材と平滑材の highly stressed volume であり, 丸棒の曲げ応力および平板の軸応力の場合について， 切欠底半径, 試験片寸法, および応力こう配の関数と しての近似式を求めている.たとえば, 浅い切欠を持 つ丸棒の回転曲げでは,

$$
\frac{K_{f}}{K_{t}}=0 \cdot 8^{0.034}\left(\frac{r_{n}^{0.051}}{r_{s}^{0.017} d^{0.034}}\right)
$$

と表わせる。（2 )式において，一般の平滑材について 見られるように， $r_{s} \rightarrow \infty$ (uniform section) とすると， 切欠きの形状に関係なく $K_{f} / K_{t} \rightarrow 0$ となる点について は, 実際の構造部材などでは, 平滑材でも大なり小な り応力集中がある $\left(r_{s}\right.$ は無限大にならない) から問題 にならないと，Discussion の項で述べている。

また,この解析に基づく理論線と, ほかの研究者に よる実験点とを比較して, 実験点は統計学的に合理的 なばらつき $( \pm 10 \%) の$ 範囲内にほとんどはいっており， highly stressed volume の考えが設計のための試算 式として採用しうると結論している。ほかに，K⿸广 $r_{n}$ と $K_{t}$ によって最も大きく影響されることを理論的 に述べている。

(本田和男)

(17 頁へ)

指数 0.034 は, 実験によって求めた $\log \sigma_{f}-\log V\left(\sigma_{f}\right.$ 